\title{
Survey of indoor radon (Rn-222) entry and concentrations in different types of building in Kalisz, Poland
}

\author{
H. Bem ${ }^{1}$ (1) - S. Janiak ${ }^{1} \cdot$ B. Przybył ${ }^{1}$
}

Received: 2 July 2020 / Accepted: 13 September 2020 / Published online: 10 October 2020

(c) The Author(s) 2020

\begin{abstract}
Indoor radon $\left({ }^{222} \mathrm{Rn}\right)$ was surveyed in a total of 141 individual houses and apartments used precalibrated passive PicoRad Detectors. The radon activity in the soil gas around the dwellings was simultaneously measured. The arithmetic mean values of indoor radon concentrations for detached houses, old buildings (up to four-stories), prefabricated blocks of flats (mostly five stories) and high-rise residential buildings (10-stories) were:, 70.9; 46.5; 38.4, and $56.6 \mathrm{~Bq} \mathrm{~m}^{-3}$, respectively. The average arithmetic mean value for all measured rooms equals $51.8 \mathrm{~Bq} \mathrm{~m}^{-3}$. The calculated average effective dose from indoor radon for the local population was equal to $2.2 \mathrm{mSv}$.
\end{abstract}

Keywords Indoor radon concentrations $\cdot$ Pico rad detectors $\cdot$ Effective doses

\section{Introduction}

Large scale epidemiological case-control studies with subsequent individual data analysis from 13 European teams showed a linear growth of the cumulative risk of death from lung cancer with an increase in indoor radon concentration [1]. For the practical implementation of a radon protection strategy, the International Commission on Radiological Protection (ICRP) recommended an integrated approach for protection against radon exposure in all buildings, irrespective of their purpose or the status of their occupants. It also introduced an upper value of the derived reference level of $300 \mathrm{~Bq} \mathrm{~m}^{-3}$ for ${ }^{222} \mathrm{Rn}$ in dwellings [2]. A similar approach was proposed in the EU (European Union) Commission's recommendations. Under the national action plan, Member States should promote action to identify dwellings with radon concentrations (as an annual average) exceeding this reference level [3]. Moreover, the Commission strongly

\footnotetext{
H. Bem

henrybem@p.lodz.pl

S. Janiak

s.janiak@pwsz-kalisz.edu.pl

B. Przybył

bartosz.przybyl2@icloud.com

1 The President Stanislaw, Wojciechowski State University of Applied Sciences in Kalisz, ul. Nowy Świat 4, 62-800 Kalisz, Poland
}

encourages national authorities to set a national derived radon reference level as low as reasonably achievable in the range of $100-300 \mathrm{~Bq} \mathrm{~m}^{-3}$.

However, due to new epidemiological findings and the application of dosimetric models, the ICRP now suggests using nominal probability coefficients for radon exposure that are larger by a factor of almost 2 than in the former ICRP and UNSCEAR recommendations [4]. This approach leads to the doubling of the risk per unit exposure as a result of it also doubling the dose coefficients from $9 \times 10^{-6}$ to $16.8 \times 10^{-6} \mathrm{mSv} \mathrm{Bq}^{-1} \mathrm{~h}^{-1} \mathrm{~m}^{3}$. Thus, an identical radon exposure situation with the new dose coefficients would result in a doubling of doses compared with the former values. This has serious conceptual implications and is still being discussed [5].

Moreover, taking into account the new dose conversion factor for an annual indoor occupancy of $7000 \mathrm{~h}$ and an equilibrium factor of 0.4 for radon daughters, one can easily calculate annual effective doses for inhalation of radon daughters by members of public as being equal to $5.2 \mathrm{mSv}$ and $15.6 \mathrm{mSv}$ for indoor radon concentrations of $100 \mathrm{~Bq} / \mathrm{m}^{3}$ and $300 \mathrm{~Bq} / \mathrm{m}^{3}$, respectively. This range of doses can be compared with that of the $5-10 \mathrm{mSv}$ year $^{-1}$ range, recommended by the ICRP for the protection of aircraft crew occupationally exposed to cosmic radiation at typical flight altitudes of 8-12 km [6]. Although the EU Directive EU 2013/59/ EUROATOM obligates its Member States to promote action to identify dwellings with radon concentrations (as an annual 
average) that exceed the reference level of $300 \mathrm{~Bq} \mathrm{~m}^{-3}$, the classification of the radon-prone areas should be reviewed, and the areas where the expected indoor radon concentration is around $100 \mathrm{~Bq} / \mathrm{m}^{3}$ should also be included for intense survey actions.

There are several commonly used types of detectors to survey radon, for example, solid-state alpha track, activated charcoal adsorption, or active instrumental detectors [7]. To better estimate long term exposure ( 3 to 12 months) to ${ }^{222} \mathrm{Rn}$, the use of solid-state nuclear track detectors is recommended [8]. However, we previously proved that passive diffusion activated charcoal canister PicoRad detectors, which require only $24-48 \mathrm{~h}$ exposition, followed by $8 \mathrm{~h}$ radon elution to liquid scintillation solution, can also be used for the annual indoor radon inhalation dose assessment [9]. This method has been successfully used by us for large scale surveillance of indoor radon [10-12]. This method also allows correction for temperature fluctuations in the examined rooms, if necessary [13].

In our previous studies of the indoor radon concentrations in kindergarten and schools in Kalisz, we found that in more than $10 \%$ of the examined sites, the indoor radon activity concentration exceeded $100 \mathrm{~Bq} \mathrm{~m}^{-3}$, whereas the median value was a relatively low $31.5 \mathrm{~Bq} \mathrm{~m}^{-3}$ [14]. In the literature, one can find many papers dealing with the influence of various factors, including radon in sub-surface soil gas concentration and its transport to the higher floor levels, on indoor radon concentrations in residential buildings. Generally, so-called geogenic potential and building construction, including radium concentration in building materials and the radon exhalation rate from these materials, are recognized as major contributors to indoor radon levels [15]. Recently in Poland, a country-wide indoor radon survey was carried out, although it was limited mostly to small detached houses. Thus, the obtained average annual indoor radon concentration for the whole country of $160 \mathrm{~Bq} \mathrm{~m}^{-3}$ seems to be exaggerated [16], since it does not take into account fact that the almost $60 \%$ of the Polish population lives in towns where people predominantly live in prefabricated blocks or highrise buildings.

The goal of this study was to extend the indoor radon survey to different types of building to evaluate residential radon activity concentration distributions and, consequently, to assess the radiological risk for the local population.

\section{Experimental}

\section{Location description}

Kalisz is the second-largest city in the Greater Poland region, after Poznan, with a population of around 1,08,000 and covering an area of $69.8 \mathrm{~km}^{2}$. The city is located on the east border of the Fore-Sudetic Monocline in the Prosna river valley with an elevation of $108 \mathrm{~m}$ above sea level. In the deeper layers of the soil in the city limits, the occurrence of Jurassic, Upper Cretaceous, Tertiary, and Quaternary deposits have been found. The average annual temperature is $8.4^{\circ} \mathrm{C}$, and the mean annual precipitation is about $511 \mathrm{~mm}$. The urban space consists of a city center with buildings up to four stories that date from the beginning of the 20th century. They are surrounded by prefabricated blocks of flats and densely placed detached houses. Close to the city border, there are a few sites with the modern detached houses (see Fig. 1). The Arabic numbers denote the number of flats in a given area, where measurements were conducted.

\section{Calculating radon entry into different types of buildings}

Radon entry into a building greatly depends on the construction and building materials. For the model standard room, the resulting indoor radon concentration can be described by a linear differential equation [17]:

$V \times d A / d t=Q_{o} \times A_{a}+E-\left(\lambda_{e}+\lambda_{d}\right) A \times V$

where: V-volume of the room $\left(\mathrm{m}^{3}\right), \mathrm{Q}_{\mathrm{o}}$ - airflow to the room $\left(\mathrm{m}^{3} \mathrm{~h}^{-1}\right), \mathrm{A}_{\mathrm{a}}$-radon concentration in the incoming air $\left(\mathrm{Bq} \mathrm{m}^{-3}\right), \mathrm{E}-{ }^{222} \mathrm{Rn}$ exhalation rate from the walls in $\left(\mathrm{Bq} \mathrm{h}^{-1}\right), \lambda_{\mathrm{e}}$-air escaping (exchange) rate $\left(\mathrm{h}^{-1}\right), \lambda_{\mathrm{d}}-{ }^{222} \mathrm{Rn}$ decay constant $=7.5 \times 10^{-3}\left(\mathrm{~h}^{-1}\right)$ and A-indoor radon concentration in $\left(\mathrm{Bq} \mathrm{m}^{-3}\right)$. Substituting the total radon influx per one cubic meter of indoor air:

$R=\left(Q_{o} \cdot A_{a}+E\right) / V$

and for low ventilation rates: $\lambda_{\mathrm{e}} \gg \lambda_{\mathrm{d}}$ Eq. (1) becomes:

$d A / d t=R-\lambda_{e} \times A$

For the simplest situation, when the ${ }^{222} \mathrm{Rn}$ influx is constant $-\mathrm{R}$ for a certain period and assuming that for $\mathrm{t}=0$ the starting indoor radon activity is equal to $\mathrm{A}_{0}$, one can get the following solution to Eq. (3):

$\ln \left(1-\lambda_{e} \cdot A / R\right)=\ln \left(1-\lambda_{e} \times A_{0} / R\right)-\lambda_{e} \cdot t$

If the equilibrium radon activity, $A_{\text {eq }}$, is settled in the room after a certain period, then $\mathrm{dA} / \mathrm{dt}=0$ and from Eq. (3) one can get:

$A_{e q}=R / \lambda_{e}$

Substituting the expression $A_{e q}=R / \lambda e$ into Eq. (4) one can get finally:

$\ln \left(1-A / A_{e q}\right)=B-\lambda_{e} \times t$ 


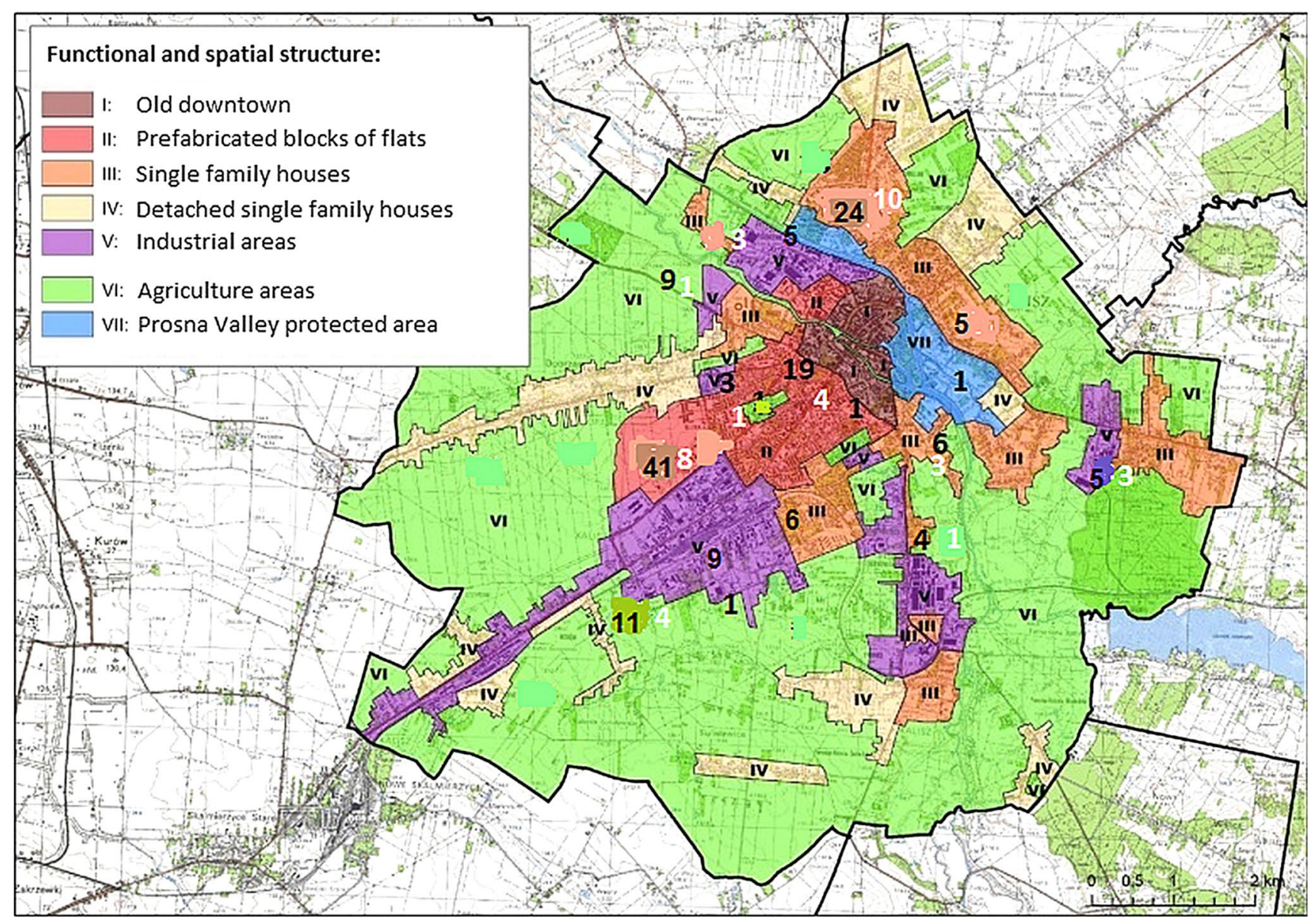

Fig. 1 Description of the indoor radon sampling areas in Kalisz

where $\mathrm{B}=\ln \left(1-\mathrm{A}_{0} / \mathrm{A}_{\mathrm{eq}}\right)$ is assumed to be constant during the time of the experiment.

Therefore, checking (after complete ventilation of the room) the activity ingrowths from $\mathrm{A}_{0}$ to an equilibrium activity of $\mathrm{A}_{\mathrm{eq}}$ as a function of time $-\mathrm{t}$, one can get a radon in air exchange ratio- $\lambda_{e}$ from the linear dependence of (6). Moreover, from Eq. (5), the total radon influx R- into the examined room can be calculated.

Such measurements can be performed by means of the Sarad EQF3220 device.

\section{Indoor radon sampling and counting}

Commercially available PicoRad plastic liquid scintillator vials with charcoal detectors were purchased from AccuStar (USA). According to the country-wide indoor radon survey, the average monthly indoor radon concentration values observed for Central Poland in March and April, as well as September and October, are very close to the annual average values [16] These data are close to those obtained for Northern Poland, where the correction coefficients were in the range of 0.9 to 1.15 , except for March and three summer months-June, July, and August [18]. The vials were exposed for $48 \mathrm{~h}$ in 2017 and 2018 (except for the above mentioned months). The whole laboratory procedure, including the calibration of each set of PicoRad detectors was basically the same as those previously published [14]. The activities of the eluted ${ }^{222} \mathrm{Rn}$ and its four short-living daughters were measured (at least $8 \mathrm{~h}$ from the beginning of elution) in the fixed channels of the liquid scintillation counter Beckman 3801 for $1 \mathrm{~h}$ each sample. The spectrum of radon and its daughters as well as the details of the optimal counting channel choice was reported elsewhere [19]. However in these experiments the average so -called calibration coefficient $\mathrm{K}$ was calculated from formula:

$K=A_{R n} / I$

where $\mathrm{A}_{\mathrm{Rn}}$ is the ${ }^{222} \mathrm{Rn}$ activity concentration in $\left(\mathrm{Bq} \mathrm{m}^{-3}\right)$ and I- average of net activities of three PicoRad calibration vials (cpm) measured in optimal canal of the Beckman counter. Such calculated value of calibration coefficient equal to $1.43 \pm 0.08$ was used for the routine indoor radon concentration determinations. 
The determination level- $\mathrm{LO}$ of the indoor radon activity concentration using Currie $<\mathrm{s}$ formula for a counting time of $3600 \mathrm{~s}$ and background in the optimal channel $\mathrm{B}=14,5 \mathrm{cpm}$, was equal to $8 \mathrm{Bqm}^{-3}$. A total relative standard deviation of the single indoor radon measurement for its concentration of $45 \mathrm{Bqm}^{-3}$ (an average value for the Kalisz area), taking into account also the standard deviation of the calibration coefficient, didn't exceed 7\%.

The quality assurance of this method was confirmed with satisfactory results obtained during the country-wide interlaboratory radon in an air comparison experiments, organized in 2018 by the Central Laboratory of Radiological Protection in Warsaw, Poland.

\section{Determination of radon in soil gas in the vicinity of detached houses}

${ }^{222} \mathrm{Rn}$ nuclide concentration in soil gas was determined in four points around each detached house site by the method described elsewhere [20]. The soil gas was removed on days without rain, usually at noon, by a typical hollow tube probe from $100 \mathrm{~cm}$ below ground level by 10 min sucking of about $3 \mathrm{dm}^{3}$ gas and passed directly through $16 \mathrm{ml}$ of water-immiscible liquid scintillator placed in standard $20 \mathrm{ml}$ scintillation vials. The activity of absorbed radon nuclides was measured by the TRIATHLER device, and the ${ }^{222} \mathrm{Rn}$ concentration in the soil gas was calculated on the basis of the previously described procedure [21].

\section{Results and discussion}

\section{Radon entry rates for detached single-family houses}

The linear dependence described by Eq. (6) for radon influx into two rooms in the same house is presented in Fig. 2.

The radon entry parameters were calculated based on the obtained linear relationships according to Eq. (6) for different rooms in detached houses (Table 1).

The low values of the radon entries $\left(\mathrm{R}<10 \mathrm{~Bq} / \mathrm{m}^{3 \mathrm{~h}-1}\right)$ and resulting low indoor radon equilibrium concentrations (below $100 \mathrm{~Bq} \mathrm{~m}^{-3}$ ) were typical for houses with (a) Sosnowa

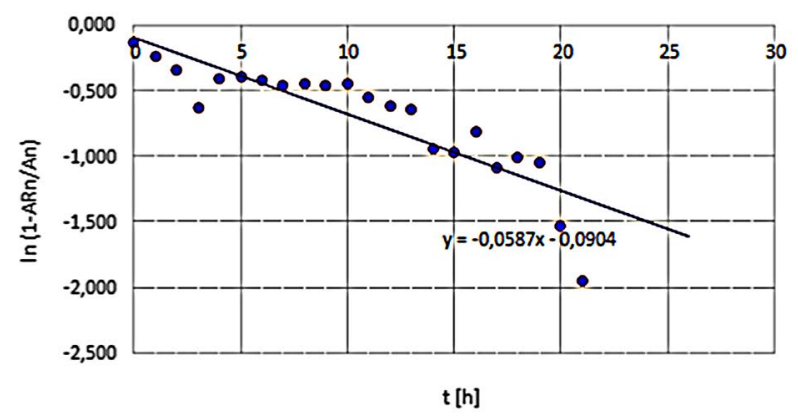

(b) I Sosnowa

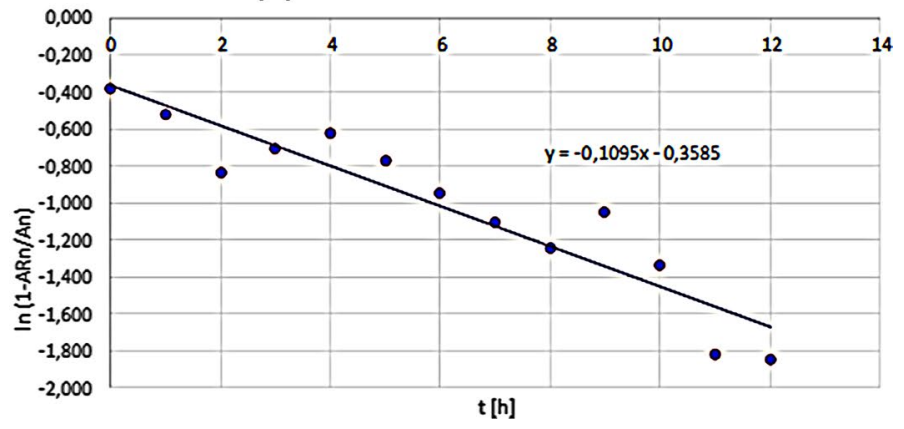

Fig. 2 Radon entry to two rooms in the same house: $\mathbf{a}$ ground floor $\mathbf{b}$ first floor

Table 1 Radon entry parameters in the different rooms

\begin{tabular}{|c|c|c|c|c|c|c|c|c|}
\hline \multirow[t]{2}{*}{ House-street } & \multicolumn{3}{|c|}{ Radon concentration $\mathrm{A}_{\mathrm{Rn}}\left(\mathrm{Bq} \mathrm{m}^{-3}\right)$} & \multicolumn{2}{|c|}{ Exchange ratio $\lambda_{\mathrm{e}}\left(\mathrm{h}^{-1}\right)$} & \multicolumn{2}{|c|}{ Radon entry-R $\left(\mathrm{Bq} \mathrm{m}^{-3} \mathrm{~h}^{-1}\right)$} & \multirow[t]{2}{*}{$\mathrm{R}_{\mathrm{o}} / \mathrm{R}$} \\
\hline & Ground floor & First floor & $\mathrm{A}_{0} / \mathrm{A}_{1}$ & Ground floor & First loor & Ground floor- $\mathrm{R}_{\mathrm{o}}$ & First floor- $\mathrm{R}_{1}$ & \\
\hline Classical house-University campus & 210 & - & & 0.21 & - & 44.1 & - & - \\
\hline Passive house-University campus & 35 & - & & 0.19 & - & 6.1 & - & - \\
\hline Radosna & 199 & 46.7 & 4.3 & 0.1 & 0.02 & 19.1 & 0.9 & 21.2 \\
\hline Rubinowa & 85.2 & 69.8 & 1.22 & 0.076 & 0.038 & 6.5 & 2.6 & 2.5 \\
\hline Długa & 249 & 194 & 1.28 & 0.09 & 0.11 & 21.6 & 21.7 & 1 \\
\hline Michałowskiego & 194 & 124 & 1.56 & 0.19 & 0.13 & 36.9 & 16.2 & 2.3 \\
\hline Podkowińskiego & 249 & 142 & 1.75 & 0.07 & 0.1 & 16.7 & 14.2 & 1.2 \\
\hline Sosnowa & 267 & 69.4 & 4.41 & 0.07 & 0.1 & 16.0 & 7.6 & 2.1 \\
\hline Szeroka & 288 & - & & 0.075 & - & 21.6 & - & - \\
\hline Kossaka & 29.1 & - & & 0.18 & - & 5.2 & - & - \\
\hline Panorama & 44.9 & - & & 0.15 & - & 6.7 & - & - \\
\hline
\end{tabular}


careful basement isolation finishing. However, comparing the indoor radon concentrations in the ground floor and first floor rooms $\left(\mathrm{A}_{0} / \mathrm{A}_{1}\right)$ with corresponding radon entries $\left(\mathrm{R}_{0} /\right.$ $R_{1}$ ) shows a lack of correlation. It indicates that a simple assumption that incoming air on the ground floor and first floor is characterized by the same radon concentration, $\mathrm{A}_{\mathrm{a}}$, is not valid. It is obvious since incoming soil gas with higher ${ }^{222} \mathrm{Rn}$ concentration makes a substantial contribution in the ground level rooms, whereas for the first floor rooms, air from ground level rooms, as well as from outdoors, with low ${ }^{222} \mathrm{Rn}$ concentration, is mostly transported. Nevertheless, the radon entry values in the ground level rooms calculated by the elaborated simplified method can be a valuable tool in predicting whether that particular house construction will be a "radon-resistant" solution or if it needs further basement sealing work.

\section{The fluctuation of daily indoor radon concentrations in two rooms determined by 3-day consecutive exposition of PicoRad vials for 1 month}

The PicoRad method, from its nature of $48 \mathrm{~h}$ exposition, gives a very good averaging of diurnal radon fluctuations in the examined rooms. The crucial problem for applying the PicoRad method for indoor radon evaluation is the relation between one single measurement using that method and the average monthly ${ }^{222} \mathrm{Rn}$ concentration. Therefore, the PicoRad detectors were exposed continuously for 3 days in two rooms for 1 month. The fluctuations of the radon concentrations during this time are shown in Fig. 3.

The measured indoor radon concentrations for ground and first floor rooms were in the range of 76.5 to $105 \mathrm{~Bq}$ -3 , with an arithmetic mean of $88 \pm 9 \mathrm{~Bq} \mathrm{~m}^{-3}$, and 46 to

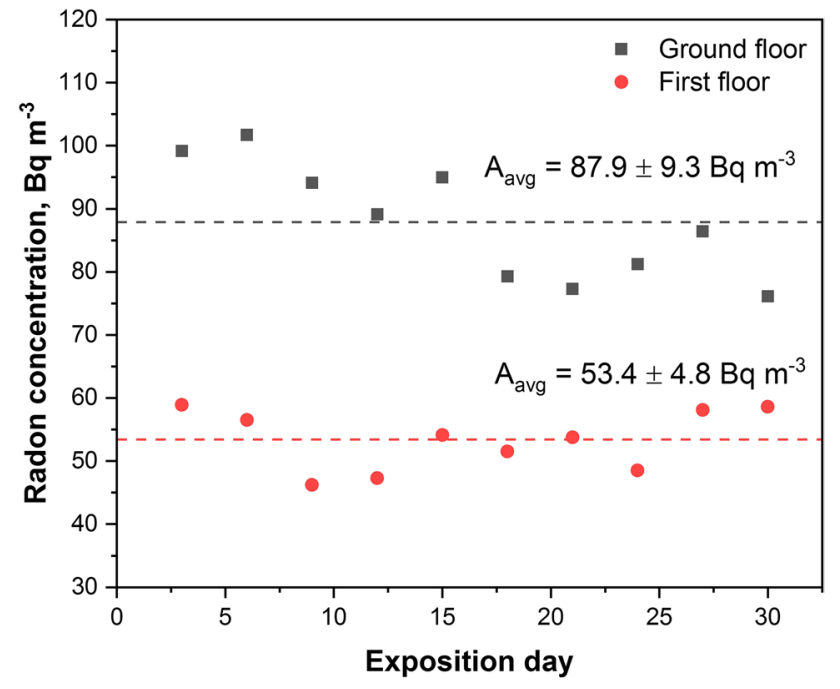

Fig. 3 Daily indoor radon fluctuations in two rooms of the one family building
$59 \mathrm{~Bq} \mathrm{~m}^{-3}$, with an arithmetic mean $53 \pm 5 \mathrm{~Bq} / \mathrm{m}^{3}$, respectively. As is evident from Fig. 3, all results were in the range of two standards deviations from the monthly mean values, and each single measurement was burdened with a relative deviation less than $\pm 20 \%$ of the monthly average value. Such an accuracy level is commonly accepted in radiological dose evaluations. Therefore, a single PicoRad method measurement can also be used for monthly evaluation of the indoor radon levels with reasonably accuracy.

\section{Indoor radon distribution}

Generally, there are four types of residential buildings in Kalisz:

- Small detached houses; mostly are relatively new with up to two stories (ground and first floor)

- Old, multifamily freestanding residential buildings, up to five stories, made of bricks

- Five-story prefabricated block of flats

- Ten-story high-rise buildings

Altogether, the indoor radon concentrations were measured in 141 rooms. The observed radon concentrations ranged between $10 \mathrm{~Bq} \mathrm{~m}^{-3}$ and $350 \mathrm{~Bq} \mathrm{~m}^{-3}$. The measurements in the detached houses involved the ground and first floors, while in the five-story prefabricated blocks, lower $(0 \div 2$ and and upper (3-5) stories, separately, in order to check for the possible influence of the subsurface soil gas penetration into the building. The distribution of indoor radon concentrations for three types of buildings, and finally for all rooms, are shown in Fig. 4. The calculated distribution parameters for each group of buildings are collected in Table 2.

As expected, higher indoor radon values were observed on the ground floors of the individual houses that were up to two stories. However, because of the high level of the result dispersion for this group, one can recognize that, according to the Student's test, the arithmetic mean difference between the radon concentrations in the ground floor and first-floor rooms were statistically significant for the p-level equals to 0.1 , only. It could confirm fact that radon in soil gas escaping to the basements of these houses is an important source of indoor radon in the small detached houses. However, for the five-story prefabricated blocks such a difference for the lower level and upper level flats was statistically insignificant. Moreover, comparing the indoor radon concentrations in detached houses with the radon concentration in the soil gas for the close vicinity of these houses showed only a very week, almost insignificant correlation $\left(\mathrm{R}^{2}=0,1\right)$, as can be seen in Fig. 5 . 

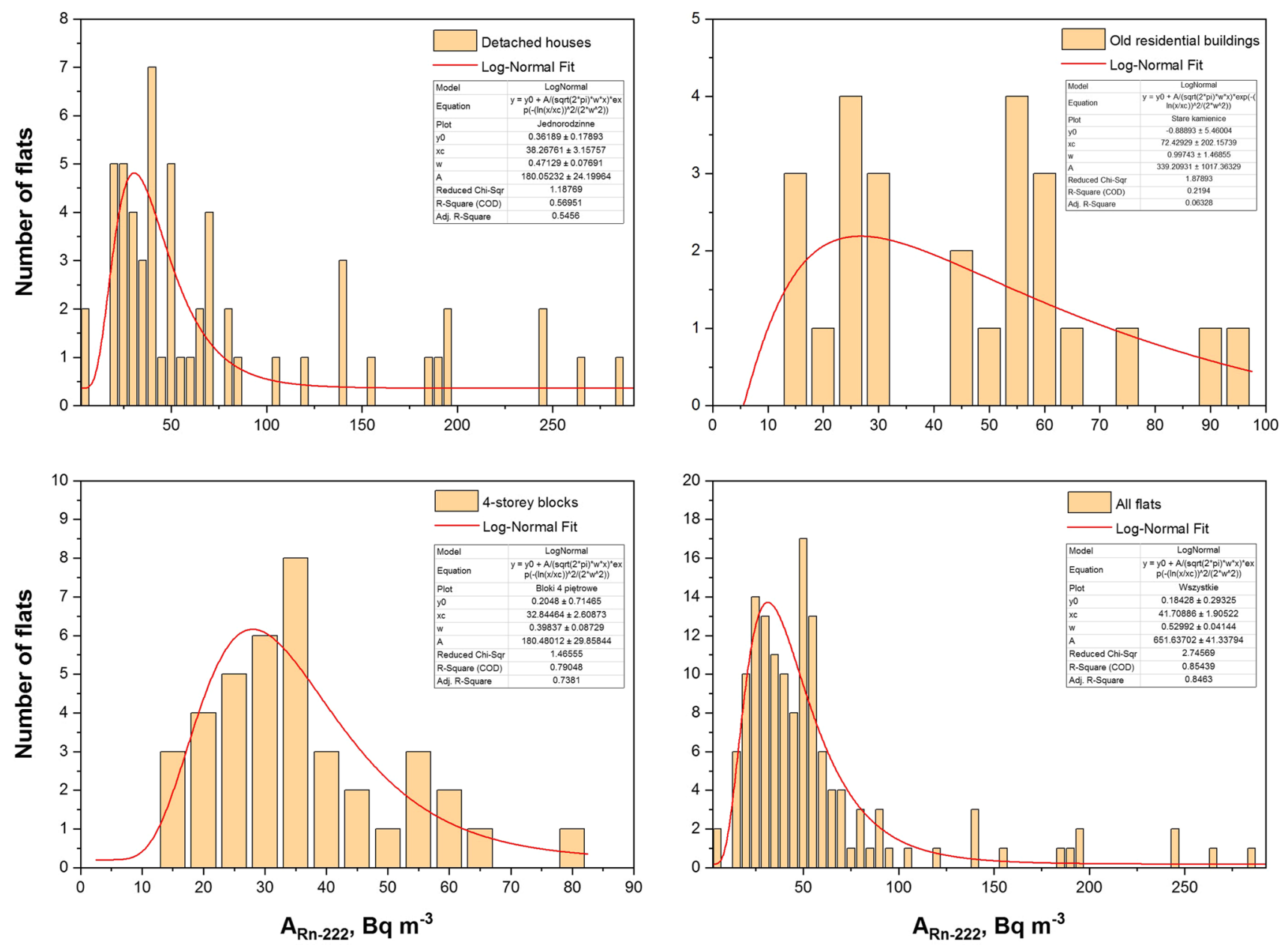

Fig. 4 The lognormal distribution of indoor radon in different groups of buildings

Table 2 Indoor radon distribution in different types of building in Kalisz

\begin{tabular}{|c|c|c|c|c|c|c|c|}
\hline \multirow{3}{*}{$\begin{array}{l}\text { Parameter } \\
\text { Number of flats }\end{array}$} & \multicolumn{2}{|c|}{ Detached single-family houses } & \multirow{4}{*}{$\begin{array}{l}\text { Old houses -up to } \\
4 \text { stories } \\
25\end{array}$} & \multirow{2}{*}{\multicolumn{2}{|c|}{$\begin{array}{l}\text { Prefabricated } \\
\text { 5-story blocks of } \\
\text { flats } \\
\text { Floors }\end{array}$}} & \multirow{4}{*}{$\begin{array}{l}\text { Prefabricated 10-story } \\
\text { high-rise flats } \\
20\end{array}$} & \multirow{4}{*}{$\begin{array}{l}\text { All homes } \\
141\end{array}$} \\
\hline & \multirow[t]{2}{*}{ Ground floor } & \multirow[t]{2}{*}{ First floor } & & & & & \\
\hline & & & & $0-2$ & $3-4$ & & \\
\hline & 34 & 23 & & 17 & 22 & & \\
\hline Arithmetic mean $\left(\mathrm{Bq} \mathrm{m}^{-3}\right)$ & 91.4 & 60.8 & 46.5 & 39.9 & 36.9 & 56.6 & 51.8 \\
\hline Geometric mean $\left(\mathrm{Bq} \mathrm{m}^{-3}\right)$ & 51.8 & 55.9 & 41.4 & 36.6 & 34.6 & 45.6 & 42.9 \\
\hline $\begin{array}{l}\text { Median } \\
\left(\mathrm{Bq} \mathrm{m}^{-3}\right)\end{array}$ & 56.9 & 46.4 & 49.4 & 38.0 & 34.4 & 53.2 & 46.4 \\
\hline $\begin{array}{l}\text { Annual effective } \\
\text { dose (mSv) }\end{array}$ & 2.7 & 2.2 & 2.3 & 1.8 & 1.6 & 2.5 & 2.2 \\
\hline
\end{tabular}

Therefore, these results confirm the predominant effect of the building construction on the indoor radon concentrations in this type of buildings observed in the experiments.
On the other hand, the unexpected increased indoor radon levels in the high-rise blocks in comparison with those for the five-story prefabricated blocks can be explained by substantial input of radon exhalation from the different kinds of 


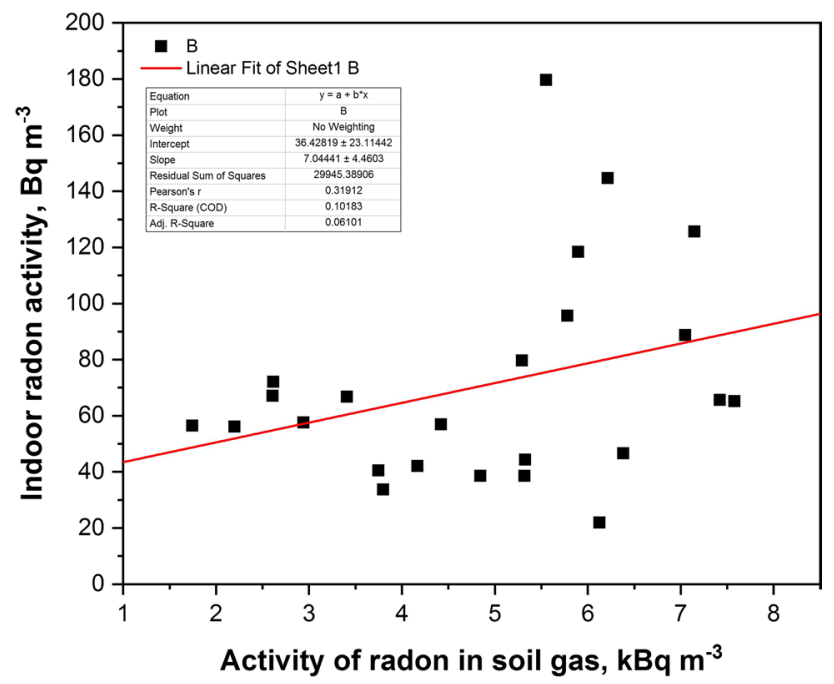

Fig. 5 Dependence of the indoor radon concentrations on the radon in adjacent soil gas

building materials, especially the so-called lightweight concrete used in high-rise building construction, which has ash as an additive. It has been proven that such building materials contain increased radium activity [22]. Elevated indoor radon levels have also been reported recently for high-rise blocks in Serbia [23].

The arithmetic mean values of indoor radon concentrations for this study are very close to those obtained previously for kindergartens and schools in the same city [14] or in the towns of Podlasie Province in Poland [18]. They also correspond to recently published indoor radon data for the city of Wroclaw in Poland [24]. However, for the annual effective dose calculation from Eq. (7), the median values of radon concentrations were taken

$E_{\text {inh }}=D C F \times A_{R n} \times F \times t$

where DCF is the radon dose conversion factor for radon inhalation, $\left.\mathrm{DCF}=16.8 \times 10^{-6}\left(\mathrm{mSv} \mathrm{Bq}^{-1} \mathrm{~h}^{-1} \mathrm{~m}^{3}\right)\right] \mathrm{A}_{\mathrm{Rn}}$ is the median radon concentration of $46.4 \mathrm{~Bq} \mathrm{~m}^{-3} \mathrm{t}$ is the average annual indoor occupancy in hours, $\mathrm{t}=7000 \mathrm{hF}$ is the indoor radon daughters equilibrium factor, $\mathrm{F}=0.4$

The calculated average annual effective dose for adult inhabitants of Kalisz was equal to $2.2 \mathrm{mSv}$.

\section{Conclusions}

The results of the indoor radon survey in Kalisz, Poland performed using the PicoRad method show that the median values of indoor radon concentration ranged from 34.4 to $56.9 \mathrm{~Bq} \mathrm{~m}^{-3}$ for different types of residential buildings. The highest values were observed for ground floor rooms in detached houses, whereas the lowest were found in five-story prefabricated blocks. It is the type of building construction that is the major factor influencing the moderate values of indoor radon in this area This is confirmed by the almost negligible correlation between radon in soil gas and indoor radon levels in detached houses and the observed radon entries into these houses.

\section{Compliance with ethical standards}

Conflict of interest The authors declare that they have no conflict of interest.

Open Access This article is licensed under a Creative Commons Attribution 4.0 International License, which permits use, sharing, adaptation, distribution and reproduction in any medium or format, as long as you give appropriate credit to the original author(s) and the source, provide a link to the Creative Commons licence, and indicate if changes were made. The images or other third party material in this article are included in the article's Creative Commons licence, unless indicated otherwise in a credit line to the material. If material is not included in the article's Creative Commons licence and your intended use is not permitted by statutory regulation or exceeds the permitted use, you will need to obtain permission directly from the copyright holder. To view a copy of this licence, visit http://creativecommons.org/licenses/by/4.0/.

\section{References}

1. Darby S, Hill D, Auvinen A, Barros-Dios JM, Baysson H, Bochicchio F, Deo H, Falk R, Forastiere F, Hakama M, Heid I, Kreienbrock L, Kreuzer M, Lagarde F, Makelainen I, Muirhead C, Oberaigner BW, Pershagen G, Ruano-Ravina A, Ruosteenoja E, Rosario AS, Tirmarche M, Tomasek L, Whitley E, Wichmann HE, Doll R (2005) Radon in homes and risk of lung cancer: collaborative analysis of individual data from 13 European case-control studies. BMJ 330:223

2. ICRP (2017) International commission on radiological protection. Occupational intakes of radionuclides: part 3. ICRP Publication 137. Ann ICRP 46(1):314-317

3. EU Council Directive 2013/59/Euratom of 5 December $2013 \mathrm{https}$ ://eur-lex.europa.eu/legal-content/EN/TXT/?uri=CELEX\%3A320 13L0059

4. UNSCEAR (2006) United Nations Scientific Committee on the Effects Of Atomic Radiation 2006 Report Vol II Annex E New York

5. Muller WU, Giussani A, Ruhm W, Lecomte JF, Harrison J, Kreuzer M, Sobotzki C, Breckow J (2016) Current knowledge on radon risk: Implications for practical radiation protection? Radiat Environ Biophys 55:267-280

6. ICRP (2016) Radiological protection from cosmic radiation in aviation. ICRP Publ 132 Ann ICRP 45(1):1-48

7. IAEA Safety Standards (2015) Protection of the public against exposure indoors due to radon and other natural sources of radiation, jointly sponsored by the IAEA, WHO. Specific Safety Guide No. SSG-32. STI/PUB/1651

8. Fairchild R, Tjong L, Wright $\mathrm{T}$ (2011) Automating radon solid state track detector measurements. Radiat Measure 46(12):1773-1777 
9. Bem H, Ostrowska M (2000) Influence of the temporal variations of indoor radon concentrations on the annual dose assessment on the base of Pico-Rad detector screening. In: Proceedings of 5th international conference on high levels of natural radiation and radon areas, radiation dose and health effects, Munich

10. Bem H, Domanski T, Bakir YY, Al-Zenki S (1996) Radon survey in Kuwait houses. In: Proceedings of the international conference IRPA 9, vol 2. International Radiation Protection Association, Vienna, Austria, pp. 101-103

11. Bem H, Ostrowska M, Bem EM (1999) Application of pulse decay discrimination liquid scintillation counting for indoor radon measurement. Czech J Phys 49(Suppl S1):97-101

12. Bem H, Bem EM, Ostrowska M (1999) Radon concentrations in kindergartens and schools in the Łodz' region of Poland. Radiat Prot Dosim 82(2): 147-149

13. Bem H, Bem EM, Chruscielewski W, Skalski H (2000) Temperature calibration of Pico-Rad detectors for radon measurement. Int J Occup Med Environ Health 13(2):147-154

14. Bem H, Bem EM, Krawczyk J, Plotek M, Janiak S, Mazurek D (2013) Radon concentrations in kindergartens and schools in two cities: kalisz and Ostrów Wielkopolski in Poland. J Radioanal Nucl Chem 295:2229-2232

15. Yarmoshenko I, Vasilyev A, Malinovsky G, Bossew P, Žunić ZS, Onischenko A, Zhukovsky M (2016) Variance of indoor radon concentration: major influencing factors. Sci Total Environ 54:155-160

16. Kozak K, Mazur J, Kozlowska B, Karpinska M, Przylibski TA, Mamont C, Grzadziel D, Stawarz O, Wysocka M, Dorda J, Zebrowski A, Olszewski J, Hovhannisyan H, Dohojda M, Kapała M, Chmielewska I, Kłos B, Jankowski J, Mnich S, Kołodziej R (2011) Correction factors for determination of annual average radon concentration in dwellings of Poland resulting from seasonal variability of indoor radon. Appl Radiat Isot 69:1459-1465

17. Jacobi W (1972) Activity and potential $\alpha$-energy of ${ }^{222} \mathrm{Rn}$ and ${ }^{222} \mathrm{Rn}$ daughters in different air atmospheres. Health Phys $22: 441-450$
18. Karpińska M, Mnich Z, Kapała J, Szpak A (2009) The evaluation of indoor radon exposure in houses. Polish J Environ Stud 18(6):1005-1012

19. Bem H, Plota U, Stanisłąwska M, Bem EM, Mazurek D (2014) Radon $\left({ }^{222} \mathrm{Rn}\right)$ in underground drinking water supplies of the Southern greater Poland region. J Radioanal Nucl Chem 299:1307-1312

20. Bem H, Gąsiorowski A, Szajerski P (2020) A fast method for the simultaneous determination of soil radon $\left({ }^{222} \mathrm{Rn}\right)$ and thoron $\left({ }^{220} \mathrm{Rn}\right)$ concentrations by liquid scintillation counting. Sci Total Environ. https://doi.org/10.1016/j.scitotenv.2019.136127

21. Bem H, Długosz-Lisiecka M, Janiak S, Mazurek D, Szajerski $\mathrm{P}$ (2017) Fast determination of indoor radon $\left({ }^{222} \mathrm{Rn}\right)$ concentration by liquid scintillation counting. J Radioanal Nucl Chem 312(2):337-342

22. Gil DM, Golewski GL (2019) Natural radioactivity of concrete with concentrated silica fume (SF) and siliceous fly ash (FA) addition. Acta Sci Pol Architectura 18(1):59-67

23. Udovicic V, Veselinovic N, Maletic D, Banjanac R, Dragic A, Jokovic D, Savic M, Knezevic D, Savkovic ME (2020) Radon variability due to floor level in two typical residential buildings in Serbia. Nukleonika 65(2):121-125

24. Thórz-Trzeciakiewicz DE, Olszewski SR (2019) Radiation in different types of building, human health. Sci Total Environ 667:511-521

Publisher's Note Springer Nature remains neutral with regard to jurisdictional claims in published maps and institutional affiliations. 